Article

\title{
The Effects of Provincial and Individual Religiosity on Deviance in China: A Multilevel Modeling Test of the Moral Community Thesis
}

\author{
Xiuhua Wang ${ }^{1, *}$ and Sung Joon Jang 2 (1) \\ 1 Department of Statistical Science, Baylor University, Waco, TX 76798, USA \\ 2 Institute for Studies of Religion, Baylor University, Waco, TX 76798, USA; Sung_Joon_Jang@baylor.edu \\ * Correspondence: xiuhua_wang@baylor.edu; Tel.: +1-254-710-1691
}

Received: 3 May 2018; Accepted: 22 June 2018; Published: 27 June 2018

\begin{abstract}
This paper examines the moral community thesis in the secular context of China Using multilevel logistic regression, we test (1) whether both individual- (measured by affiliation with Islam, Buddhism and Christianity) and aggregate-level religiosity (measured by the number of mosques, Buddhist temples, and churches per 10,000 people in province) are inversely related to law and rule violations at the individual level and (2) whether province-level religiosity enhances the inverse relationship between individual religiosity and deviant behaviors. Results from the 2010 China General Social Survey and the Spatial Explorer of Religions provide some support for the moral community proposition that contextual religiosity affects deviance at the individual level. Specifically, we find provincial as well as individual level of Islam to be inversely related with the violation of the law and rules. However, we find that neither the provincial level of Christianity and Buddhism nor cross-level interaction is related to deviance. The only exception, cross-level interaction involving the individual and provincial level of Islam, is in the opposite direction (i.e., positive, not negative). The implications of our findings are discussed.
\end{abstract}

Keywords: religion; law and rule violations; moral community; China

\section{Introduction}

The deterrent effect of religion on crime and deviance has been debated for more than 30 years, since Hirschi and Stark (1969) failed to find empirical support for the "hellfire" hypothesis. While many studies report that religion is inversely associated with various types of criminal and deviant behaviors (e.g., Benda 2002; Cochran and Akers 1989; Johnson 1987; Johnson et al. 2000, p. 2000; Johnson and Jang 2011; Marsiglia et al. 2005; Olson 1990), others find religion to be unrelated to crime and deviance, like Hirschi and Stark (Groves et al. 1987; Heaton 2006; Hirschi and Stark 1969). Some suggest that the relationship between religion and crime is spurious since both religiosity and criminal behaviors are fully attributable to the individual's neurological predisposition (Cochran et al. 1994; Ellis 1987, p. 220; Ellis and Peterson 1996).

Other scholars, however, propose explanations for the inconsistent findings. One key explanation is the moral community thesis proposed by Rodney Stark (Stark 1996; Stark et al. 1982). According to this thesis, religion is more of a group than an individual property. Thus, the effect of religious context on crime and deviance is conceptually distinct from that of individual religiosity. Moreover, the effect of individual religiosity on deviance and crime is expected to be contingent upon the religiousness of context, namely, the proportion of people who are actively religious in the context.

Not all studies, however, provide empirical support for the hypothesis that religiosity at contextual level affects individual deviance and crime (Adamczyk and Hayes 2012; Ellis and Peterson 1996; 
Finke and Adamczyk 2008; Stack and Kposowa 2011). Also, previous findings are not consistent about whether contextual-level religiosity enhances the effect of individual religiosity on crime and deviance (Adamczyk and Hayes 2012; Corcoran et al. 2012; Regnerus 2003; Wallace et al. 2007). Besides, prior research focuses mostly on Western contexts, particularly the United States, which, due to its Judeo-Christian tradition, is more likely to have a moral community than less religious non-Western contexts. To date, the moral community thesis has not been tested yet using data from non-Western societies.

To fill this gap in the research, this study examines the moral community thesis in the context of contemporary China. Specifically, we apply multilevel logistic regression analysis to analyze two sets of nationally representative data to test (1) whether aggregate-level and individual-level religiosity are inversely related to violation of the law and various conventional rules at the individual level and (2) whether the aggregate-level religiosity increases the prosocial effect of individual-level religiosity on the odds of violating the law and conventional rules. We begin with an overview of the moral community thesis and religion in China, followed by a review of the literature on religion and deviance in Chinese contexts (Taiwan as well as mainland China). Next, we describe our theoretical approach and hypotheses before turning to a description of the data measurement and analytic strategy. Finally, we present results from a multilevel logistic regression analysis and discuss the implications of our study for the moral community thesis.

\section{Moral Communities Thesis}

The moral community thesis was originally proposed by Durkheim (1976) and popularized by Stark (1996). When religiosity was found to have no association with delinquency in California and the Pacific Northwest (Burkett and White 1974; Hirschi and Stark 1969), unlike in Atlanta (Higgins and Albrecht 1977), Arizona (Jensen and Maynard 1979), Nashville (Rhodes and Reiss 1970), and among Mormons in Utah and Idaho (Albrecht et al. 1977), Stark (1996) proposed that the deterrent effect of individual religiosity on deviance and crime should be conditioned by the religiosity of the broader social context, namely the proportion of people who are actively religious in a particular social context (Stark 1996; Stark et al. 1982). Stark (1996, p. 164), religion is "a group property" rather than "an individual trait." Thus, religion is expected to produce social conformity among individuals only when a religion is accepted by most of the community members and provides a normative guideline for social interaction in the community. Accordingly, in a religious community where religious commitment is a social norm, individual religiosity is likely to be inversely associated with crime and deviance. In contrast, in a non-religious or secular community, religious individuals are as likely as their non-religious counterparts to be deviant as the religion is not accepted by their community as a social norm (Stark et al. 1982).

Since its introduction, an increasing number of studies have been conducted to test the moral community thesis. To test the thesis, it is necessary to first examine whether context-level religiosity is inversely related to individual-level deviance and crime, although the relationship is not the key argument of the thesis. Most studies find a significant association between religious context and individual deviance.

For example, by applying multilevel analysis to cross-national data, studies find that individuals living in more religious countries have lower levels of premarital sex (Adamczyk and Hayes 2012), suicide acceptability (Stack and Kposowa 2011), and acceptance of white-collar crimes (Corcoran et al. 2012) than those in less religious countries. Similarly, American adolescents attending religious schools are less likely to smoke cigarettes than those in less religious schools (Bahr and Hoffmann 2008), and the risk of suicide attempts is found to be lower among youth living in neighborhoods that had a higher proportion of religiously conservative residents in the United States (Maimon and Kuhl 2008).

Furthermore, Regnerus (2003) found religious homogeneity rather than community religiousness at a school- and county-level to generate effective social control against delinquency (Regnerus 2003; 
Trawick and Howsen 2006), while Adamczyk (2008, p. 657) found neither generic religiosity nor conservative Protestant religious context to make a difference in women's decisions regarding abortion. According to Finke and Adamczyk (2008), religiosity at a national level was among the most consistent predictors of the individual sexual morality, although it had no effect on the morality sanctioned by the state such as cheating on taxes, accepting a bribe, buying stolen goods, providing the government with false information, and avoiding a public transportation fare.

While the previous finding of an inverse relationship between context-level religiosity and individual-level deviance is consistent with the moral community thesis, the central argument of the thesis concerns whether context-level religiosity affects the individual-level relationship between religiosity and deviance. That is, Stark (1996, p. 165) argues that individual religiosity restrains crime and deviance "only in communities where the majority of people are actively religious." In a secular context, he suggests the individual-level effect of religion on crimes and deviance would substantially decline and even disappear (Stark 1996; Stark et al. 1982).

As the thesis would have predicted, Corcoran et al. (2012) found that religious context, measured in terms of belief in a personal and moral God, increases the inverse relationship between individual religious belief, specifically, a belief in a personal and moral God, and the acceptability of white-collar crimes. Scheepers et al. (2002) also showed that the effect of individual religiosity on moral attitudes (toward abortion, premarital and extramarital relationships, and homosexual relations) tended to be stronger in more religious countries than in less religious or more secularized countries. In addition, using a large representative sample of American public high schools, Wallace et al. (2007) found that adolescents attending highly religious schools were less likely to use alcohol, tobacco, and marijuana than their equally religious peers attending less religious schools.

While Regnerus (2003) reported that religiosity at the school and county level interacted with individual religiosity (religious affiliation) in reducing delinquency, he also suggested that religious homogeneity at a contextual level rather than religiosity interacts with individual religiosity reducing theft. Similarly, Ovadia and Moore (2010) found the percentage of evangelical Protestants in a county to be positively associated with the teen birth rate, whereas the percentage of Catholics was negatively associated, although the percentage of religious adherents in a county was not related to the birth rate.

Despite these positive findings, researchers have also failed to find evidence of the moral community thesis. For example, using data on suicide in Netherlands from 1936 to 1973, Van Tubergen et al. (2005) found that community-level religiosity can protect not only religious members of all denominations but also "religious nones" from suicide. Cochran and Akers (1989, p. 92) only found "minor" support for Stark's moral community thesis. That is, they did not find significant interactions between aggregate religiosity and the effect of individual religiosity on alcohol and marijuana use, although they found personal asceticism to affect alcohol use only in highly religious contexts and disappears in contexts with low levels of religiosity.

In response to the negative findings, some researchers have argued that the significant relationship between religion and delinquency at the individual level "may not have as much to do with where (or in what social context) we measure it as with how we attempt to measure it" (Junger and Polder 1993; Sloane and Potvin 1986, p. 103). In a meta-analysis of 60 studies, Baier and Wright (2001) found religious beliefs and behaviors to have a moderate deterrent effect on individuals' criminal behaviors, but the effect was not contingent upon contextual religiousness (Baier and Wright 2001). Benda and Corwyn (2001) even rejected Stark's thesis based on their finding that an inverse relationship between religion and crime exists on the irreligious East coast as well as in the South of the United States. These findings suggest that the effect of individual religiosity on deviance and crime is not conditioned by the religiousness of the context. 
Welch et al. (1991) also found no significant interaction between both individual and parish-level religiosity on adult deviance, while they were inversely related. ${ }^{1}$ Similarly, Bahr and Hoffmann (2008, p. 743) found that "the associations between individual religiosity and the four types of drug use were not affected by the level of school religiosity." Applying hierarchical modeling to cross-national data, Adamczyk and Hayes (2012) also found no significant cross-level interaction, while individual religious affiliation and the percent of Muslim residents at a country level both decreased the odds of premarital sex. Examining several deviant outcomes, Sturgis and Baller (2012) also failed to find significant interactions between contextual religiousness and the effect of individual religiosity on anti-asceticism. In sum, these studies indicate that individual and contextual religiosity tend to affect deviance independently.

Most previous studies have examined the effect of moral community on deviance and crime in the Western and particularly a U.S. context, where the Judeo-Christian tradition exists (Regnerus 2003; Stark 1996; Stark et al. 1982; Tittle and Welch 1983; Wallace et al. 2007). Few studies have examined the moral community thesis in a non-Western context, especially a society where religion is marginalized and regulated by the state. Previous researchers have suggested that the prosocial effect of religion on deviance and crimes should substantially diminish and even disappear in a secular social context because a moral community is unlikely to exist to strengthen individual religiosity (Corcoran et al. 2012; Stark 1996, 2001; Stark et al. 1982). Some have even argued that when certain religions are persecuted by the government, these religious groups would increase their grievance against the state and the broader society that did not support their agenda (Grim and Finke 2007; Hafez 2004).

To address this understudied issue, we intend to examine the moral community thesis in the context of China, where religion is regulated and even repressed in a secular society (Grim and Finke 2006, 2007; Potter 2003; Yang 2011). Thus, a brief description of the history and current state of religion in China is in order.

\section{Religion in China}

While different religions compete in a free market in the United States (Finke and Stark 2005), religion in China is marginalized and even persecuted by the government (Grim and Finke 2006, 2007; Potter 2003; Yang 2011). Historically, agnostic Confucianism is the cultural bedrock of secular orthodoxy (Creel 1932; Sun 2013; Weber and Gerth 1953; Yang 1961). After the Communist Party of China took power in 1949, Marxism-based atheism has remained the official ideology of China (Cao 2012; Yang 2004) and continues to monitor and restrict religious activities.

Since the Economic Reform in 1978, however, the Communist government has decreased its restrictions on religion, which initiated an intense growth of religion along with social and economic transitions (Potter 2003; Stark and Wang 2015; Yang 2005, 2011). Despite such growth, a large majority of the general population in China holds an atheistic or agnostic view with only a small percentage of Chinese population professing a religion. For example, while on the 2007 Spiritual Life Study of Chinese Residents 23 percent of participants reported their religious affiliation, the 2010 China General Social Survey (CGSS) revealed that only 13 percent of the population reported that they have certain religious affiliations. Similarly, according to the World Value Survey conducted in 2012, only

1 Furthermore, Tittle and Welch (1983) even found the opposite of what Stark's moral community thesis posits, although they relied on a proxy measure of aggregate religiosity constructed using individual-level survey data. That is, they reported that the inverse relationship between individual religiosity and self-estimated probability of future deviance was more likely to be significant when the proxy of aggregative religiosity was relatively low rather than high. To explain this unexpected finding, they speculated that religion might have been likely to "distinctly affect conformity only where the larger environment lacks the mechanisms that normally curtail deviance" (Tittle and Welch 1983, p. 674). Yet this finding needs to be interpreted with caution given the limited measurement of two key variables: contextual religiosity and deviance. That is, their measure of context-level religiosity based on the aggregation of individual religiosity may not be necessarily representative of the context, and the behavioral intention of future deviance may not be a good indicator of actual deviance. 
14.7 percent of respondents claimed affiliation to a religion. According to the 2010 CGSS, 5.5 percent of the survey respondents identified Buddhism as their religion, with 2.2 percent Christianity, 2.4 percent Islam, 0.2 percent Taoism, and 2.3 percent folk religion.

Given its marginal social position in a secular society, many scholars have speculated that religion has no positive effect on morality or general trust in Chinese society (Hu 2013; Stark 2001). Even fewer studies have examined whether religion in China affects crime and deviance and promotes social conformity. At a micro level, the religion-deviance link in China is quite understudied, while most studies to date suggest no relationship or even positive association between religion and deviance. For example, religion is found to be positively associated with suicide attempts among both college students and rural women in China (Zhang and Jin 1996; Zhang and Xu 2007; Zhao et al. 2012).

Cross-national studies usually consider China a generally secular nation where religion barely has any social influence. For example, by comparing data from China, Taiwan, and the USA, Zhang and Thomas (1994) found that religion in both China and Taiwan does not increase social conformity among college students, perhaps because social conformity is primarily promoted by the Confucian tradition. Meanwhile, Stark (2001, p. 620) asserts that "the moral behaviors of individuals would be influenced by their religious commitments only in societies where the dominant religious organizations give clear and consistent expression to divine moral imperatives." In China, Confucianism and the dominant religions-Daoism, Buddhism, and folk religion—are somewhat amalgamated. In other words, gods of these religions are borrowed from each other, sometimes sharing the same teachings with one another (Shahar and Weller 1996). Consequently, religious beliefs and practices in China are likely to have little effect on moral judgments as those gods are "of very limited power and scope and usually lack moral concern and even dignity" (Stark 2001).

These studies, however, have three major limitations. First, they fail to differentiate institutional religions from folk religions despite their potential differences in affecting deviance. On the one hand, folk religions have very diverse and even inconsistent beliefs and practices (Dean 2003; Tamney 1998; Yang 2010), whereas organized religions, also called "institutional" religions by Yang (1961), have developed systems of religious orthodoxy, moral norms, ritual practice, and professional clergies or religious institutions distinct from secular social life. On the other hand, in institutional religions, especially Christianity and Islam, there are "all-powerful, all-seeing gods ruling the entire universe as the ultimate deterrent" (Stark 2001, p. 621). Therefore, individuals can develop higher morality and moral behaviors with a conception of a powerful and moral God in mind (Corcoran et al. 2012).

In contrast, innumerable gods and deities exist in folk religions, many of which are shared by or borrowed from each other (Dean 2003; Shahar and Weller 1996). Having folk religion seldom implies "a long-standing, deeply-felt relationship with a god but merely involves requests for favors from various divinities of small scope" (Stark 2001, p. 634). Consequently, folk religions have limited power and scope in influencing individuals' morality. Instead, they function as a placebo for self-centered and self-serving individuals (Stark 2001). Thus, folk religions in China are less likely to prohibit crimes and deviance than institutional religions. Even if some folk religions do have prosocial teachings, it is hard to find a significant association between folk religion and crimes and deviance behaviors in statistics considering such diverse religious doctrines and practices in folk religion (Yang and Hu 2012).

Second, those studies failed to consider that the levels of religious regulation may vary not only across religions but also among regions. Under state regulations, a triple religious market exists in contemporary China: (1) a "red market" approved by the government; (2) a "black market" banned by the government; and (3) a "gray market" ambiguously treated by the government (Yang 2006). The organized religions of Christianity (both Protestantism and Catholicism), Islam, Buddhism, and Daoism are in the red market recognized by the government, whereas Falun Gong, Eastern Lightning, and other new religions are in the black market forbidden by the government (Chan 2004). On the other hand, various types of folk religions (i.e., sectarian, communal, and individual folk religions) 
have been thriving in the gray market due to their ambiguous legal status (Dean 2003; Wenger 2004; Yang and Hu 2012). ${ }^{2}$

Although the central government of China regulates and even persecutes religion in general across the country, the development of religion is highly dependent on the daily interactions and negotiations between religious organizations and local government (Koesel 2014). For example, Cao's (2010) ethnographic study of Wenzhou Christians demonstrates how Christian leaders cooperate with local authorities, and Wang and Ya's (2015) study describes in detail how the Three-Self Church succeeded in expanding their influence by establishing a stable relationship with the local officials. In addition, some local governments would decrease religious regulation and even provide opportunities for the growth of religion when they try to help local economies thrive by using local religious resources (Feuchtwang 2010; Koesel 2014; Palmer and Wickeri 2011). Thus, a variation in the level of religious regulation is likely to exist across provinces, though no empirical research has examined this phenomenon yet.

Third, previous researchers failed to incorporate the fact that different religions tend to concentrate in different parts of China into their studies. As described by Palmer and Wickeri (2011, p. 3), "Buddhists visit a popular temple in east China to burn incense or to ask the monks to conduce special service for their families. Villagers gather at festival time to usher in the lunar New Year and perform a communal sacrifice to the local gods [in Southeastern China]. Muslims in far Western China proceed to their neighborhood mosque five times a day for prayers.... Tibetan Monks demonstrate for religious freedom in a small city outside Lhasa." Protestant Christians are highly concentrated in Henan, Anhui, Zhejiang, Jiangsu, Fujian, and Yunan province (Stark and Wang 2015; Ying 2009), forming three major "Bible Belts" in China (Yu 2010: the Huai River Basin Bible Belt (Henan, Anhui and Northern Jiangsu); the Minzhe coastal Bible Belt (Fujian and Zhejiang); and the Shaanxi-Yunnan Bible Belt (Shaanxi and Yunnan). Due to its long history of missionary work, Catholicism in China is highly concentrated in North China, especially in Hebei and Tianjin (Madsen 1998). Muslims are highly concentrated in Northwestern China, including Xinjiang, Ningxia, Gansu, and Qinghai Province (Davis 2008; Gladney 1996), while Tibetan Buddhists are the majority of the population in Tibet. On the other hand, Southeast China, such as Fujian, Guangdong, and Jiangxi Provinces are famous for their various folk religions (Dean 2003; Palmer and Wickeri 2011).

The concentration of a particular religion, especially homogeneous institutional religions, in a certain region may: (1) generate and influence shared social norms among individuals in that region through social interactions, rites, and rituals (Durkheim 1926; Stark 1996; Stark et al. 1982); (2) internalize individuals with the conception of powerful, morally conscious god(s) (Corcoran et al. 2012; Stark 2001); and (3) provide dense networks and social capital that enhance civic engagement, social trust, and social and psychological support and control for community members (Lee 2006; Lee and Bartkowski 2004; Regnerus 2003; Tsai 2007). We intend to examine whether institutional religion (Islam, Buddhism, and Christianity) at provincial level shapes a moral community that alters the effect of individual religiosity on law and rule violation, focusing on three religions: Islam, Buddhism, and Christianity. ${ }^{3}$

2 This argument may not be that true after 2013 since the government began to have higher restrictions on Christianity and Islam. However, before 2013, folk religions were given less space to develop compared with institutional religions.

3 We decided not to examine folk religion for two reasons. First and foremost, there are no data available to measure the presence of folk religion at provincial level. Second, based on our previous argument, folk religions are less likely than institutional religions to shape a moral community in secular China for three reasons: (1) folk religions are unlikely to generate a common moral order for individuals because of their numerous gods and deities (Corcoran et al. 2012; Stark 2001); (2) folk religions lack a systematic orthodoxy and structures to constrain individual behaviors (Yang 1961); and (3) folk religions serve primarily as a utilitarian tool for self-centered and self-serving individuals (Chen 1995; Stark 2001; Wang and Jang 2017). 


\section{Hypotheses}

Taken together, using province as aggregate unit, we test the following hypotheses.

Hypothesis 1: Individual-level religiosity (i.e., affiliation with Islam, Buddhism, and Christianity) is inversely related to individual-level deviance.

Hypothesis 2: Province-level religiosity (i.e., the prevalence of mosques, Buddhist temples, and churches) is inversely related to individual-level deviance.

Hypothesis 3: Province-level of religiosity enhances the inverse relationship between individual-level religiosity and deviance.

\section{Methods}

\subsection{Data}

Data we analyzed come from multiple sources: the 2010 Wave of China General Social Survey (henceforth, CGSS 2010) and the Spatial Explorer of Religions, collected between 2002 and 2004. First, the CGSS 2010 resembles the General Social Survey of the United States and includes a series of questions about deviant behaviors, such as violation of the law and government, workplace, organization, and transportation rules. A multistage sampling design was used to obtain a nationally representative sample of individuals from each of 22 provinces and four municipalities (Beijing, Shanghai, Tianjin, and Chongqing). The first 100 counties (or districts) were selected randomly across China, while five major cities (Beijing, Shanghai, Tianjin, Guangzhou, and Shenzhen) were treated as the primary sampling unit. Second, from each county, four communities or villages were randomly drawn. Then 25 households were randomly selected from each community, and, finally, one individual, age 18 or older, was randomly chosen from each household. From the five major cities, a total of 80 communities were randomly selected. In the end, 480 communities of administrative units and villages were selected, and the total sample size of individual respondents was 11,770. Second, province-level religiosity is measured based on data from the Spatial Explorer of Religions, made available by the China Data Center at Michigan University. ${ }^{4}$ The Spatial Explorer of Religion provides the number of religious sites of Buddhism, Daoism, Christianity, and Islam that existed in 31 provinces during the period of 2002-2004 (Bao et al. 2014). Third, income inequality at provincial level is measured using the Theil Index, published by Lu and Xu (2004), while the index is not available for four municipalities: Beijing, Tianjin, Shanghai, and Chongqing. Fourth, total population in each province comes from 2010 China Census data. ${ }^{5}$ Fifth, the percentages for the Communist party members in each province are clustered by the self-reported Communist party member in China GSS 2010. Finally, other provincial characteristics such as illiteracy rate, urbanization rate, GDP per capita, and ethnic composition were obtained from the 2010 China Census data.

As explained, we focus only on institutional religion, so followers of folk religion are excluded from our analysis. In addition, Tibet is dropped because the unit contains fewer than 30 valid cases at individual level. As a result, the final sample consists of 9528 valid cases from 25 provinces.

4 The link to the website: http://chinadataonline.org/religionexplorer/religion40/\#; accessed on 2016-05-20.

5 Administrative Divisions of People's Republic of China, from Chinese government website: http://www.gov.cn/test/200506/15/content_18253.htm, accessed on May 24th, 2016. 


\subsection{Measurement}

\subsubsection{Dependent Variables}

To measure the violation of conventional authority, we use five items asking about conforming behavior: "To what extend have the following behaviors happened to you: abiding by the motor vehicle regulations/workplace rules and regulations/government policies and regulation/by the law/organizational rules?" ( $1=$ not at all, $2=$ rarely, $3=$ sometimes, $4=$ very often, $5=$ always $)$. The response categories are reverse-coded so a higher score represents more frequent violation. As anticipated for a general population, the items' distributions are highly skewed. For example, 69.2 percent of respondents reported that they never violated the law, whereas the remaining 30.8 percent said they did rarely $(29.0 \%)$, sometimes $(1.3 \%)$, very often $(0.3 \%)$, or always $(0.2 \%)$. To address this skewness, the item is dichotomized: $0=$ no violation and $1=$ violation. For the same reason, four items of rule violation are also dichotomized. ${ }^{6}$

\subsubsection{Individual-Level Independent Variables}

Religiosity. Three dummy variables are created to measure an individual's religiosity, one for each of three religions. Respondents who identified themselves as Muslim, Buddhist, and Christian (including Protestants and Catholics) are coded as 1, and religious nones (i.e., no religious affiliation) is the referenced group. ${ }^{7}$

Sociodemographic Characteristics. To control for various sources of spuriousness, we construct sociodemographic variables: age, gender $(0=$ male, $1=$ female $)$, ethnicity $(0=$ Han majority, 1 = non-Han minority), education $(0=$ no education, $1=$ elementary school, $2=$ middle school, $3=$ high school, $4=$ Junior college; $5=$ college and above), annual personal income (logged), employment status $(0=$ employed, $1=$ unemployed $)$, marital status $(0=$ single, divorced, separated, or widowed, $1=$ married $)$, place of residence $(0=$ rural $1=$ urban $)$, and Communist Party membership $(0=$ no, $1=$ yes $)$.

\subsubsection{Province-Level Independent Variables}

Religiosity. To measure aggregate-level religiosity, the number of mosques, Buddhist temples, and churches per 10,000 residents of each province is calculated. We use the rate of religious sites for two reasons: one is the lack of data available to measure the percentage of people affiliated with institutional religion in each province, and the other is the assumption that a higher percent of residents with religious affiliation in a province would lead to a higher number of religious sites in the province, which makes the rate of religious sites a reasonable proxy of province-level religiosity.

Sociodemographic Characteristics. GDP per capita of 2010 is used to measure the level of economic development of each province, and illiteracy rate is employed as a measure of province's educational level. Another measure of province-level socioeconomic status, the Theil Index (similar to the Gini Index), is included in analysis to control for income inequality within province. The urbanization rate is operationalized by the percentage of urban population in each province in 2010, whereas the total population of province is measured in units of 10,000 people. Finally, we measure ethnic heterogeneity

6 Likewise, 63.3 percent respondents reported that they had never violated government laws, whereas 36.7 percent said that they did rarely $(33.2 \%)$, sometimes $(2.8 \%)$, very often $(0.4)$, or always $(0.3)$. Almost 60 percent $(58.2 \%)$ of respondents reported that they had never violated transportation laws, whereas 41.8 percent said that they did rarely $(36.3 \%)$, sometimes $(3.8 \%)$, very often $(1.3)$, or always $(0.4)$. About the same majority $(60.4 \%)$ reported that they had never violated workplace rules at all, while $35.2,3.2,0.7$, and 0.5 percent reported they did very rarely, sometimes, very often, and always, respectively. Similarly, $65.5,31.6,2.2,0.3$, and 0.3 percent reported that they had never violated organization rules, very rarely, sometimes, very often, or always, respectively.

7 Respondents affiliated with folk religions are excluded. We also discard observations of Taoism and other religions because of their few observations $(N=22)$ in GSS2010. 
in terms of the percentage of ethnic minority (i.e., non-Han) residents in the province and construct a variable of percent Communist Party members in province given its significance in China.

\subsubsection{Analytic Strategy}

To simultaneously account for the interdependence of individuals within the same social context and model both provincial-level and individual-level variance on deviance, we conduct multilevel mixed-effects logistic regression analysis (Raudenbush et al. 2004). Thus, in our model individual deviance is explained by both individual and provincial characteristics.

We first examine whether the three variables of individual-level (i.e., being affiliated with Islam, Buddhism, and Christianity) and province-level religiosity (i.e., number of mosques, temples, and churches per 10,000 residents in province) are related to individual-level violation of conventional authority, while controlling for both provincial and individual characteristics. Then we estimate interactive model that includes three cross-level interaction terms (i.e., being affiliated with Islam $\times$ number of mosques per 10,000 residents in province, being affiliated with Buddhism $\times$ number of temples per 10,000 residents in province, and being affiliated with Christianity $\times$ number of churches per 10,000 residents in province) as well as their constituent terms to test whether the strength of the relationship between individual-level religiosity and deviance increases along with the provincial religiosity.

\section{Results}

Descriptive statistics of variables included in the analysis are summarized in Table 1. About 11 percent $(10.7 \%)$ of the final sample $(N=8224$ individual respondents in 25 provinces $)$ are affiliated with an institutional religion (2.8\% Muslim, 5.4\% Buddhists, and 2.5\% Christians), and less than half of them answered affirmatively the questions about violating the law, ranging from 31.8 percent (law violations) to 43.1 percent (transportation rule violations). Survey respondents are, on average, about 49 years old, and the sample is 51.9 percent female, 9.0 percent ethnic minority (i.e., non-Han), 81.0 percent married, 43.1 percent urban residents, 6.0 percent unemployed, and 11.4 percent Communist Party members.

The average number of religious sites in China is only 0.574 per 10,000 people, confirming that China is a highly secular country. The rates of mosques, temples and churches, however, varies across provinces. The rate of mosques is highest in Gansu, Qinghai, Ningxia, and Xinjiang; the rate of temples is highest in Qinghai, Fujian, Zhejiang, Ningxia and Jiangxi; churches are more prevalent in Zhejiang, Fujian, Anhui, Jilin, and Henan (see Figure 1).

The average GDP per capita is $25,638.77 \mathrm{RMB}(\approx \$ 3845.82)$ with the minimum and maximum being $10,301.95 \mathrm{RMB}(\approx \$ 1586.92)$ and $44,604.92 \mathrm{RMB}(\approx \$ 6862.30)$, and economic inequality, measured by the Theil index, also varies across provinces, from 0.063 (Zhejiang) to 0.489 (Guangdong). The average urban population in the provinces is about 47 percent, with the minimum and maximum being 29.9 percent (Guizhou) and 63.4 percent (Guangdong), respectively. The illiteracy rate is, on average, 7.2 percent, with the rate ranging from 3.2 percent (Liaoning) to 15.9 percent (Gansu), whereas the percentage of ethnic minorities varies widely across provinces, from 0.3 percent (Jiangxi) to 59.4 percent (Xinjiang). Finally, the percentage of Communist Party members in provinces is, on average, 11.4 percent, ranging from 7.0 percent (Hebei) to 25.3 percent (Qinghai). 
Table 1. Descriptive statistics (individual variables $N=8224$ provincial variables $N=25$ ).

\begin{tabular}{|c|c|c|c|}
\hline Variable & Mean & S.D. & Range \\
\hline \multicolumn{4}{|l|}{ Individual Level } \\
\hline $\begin{array}{l}\text { Law violation } \\
\text { "Have you ever violated the law?" }(1=\text { yes; } 0=\text { no })\end{array}$ & 0.318 & 0.466 & $0-1$ \\
\hline $\begin{array}{l}\text { Government rule violation } \\
\text { "Have you ever violated government rules?" }(1=\text { yes; } 0=\text { no) }\end{array}$ & 0.377 & 0.485 & $0-1$ \\
\hline $\begin{array}{l}\text { Working rule violation } \\
\text { "Have you ever violated working rules?" }(1=\text { yes; } 0=\text { no })\end{array}$ & 0.411 & 0.492 & $0-1$ \\
\hline $\begin{array}{l}\text { Organization rule violation } \\
\text { "Have you ever violated organization rules?" }(1=\text { yes; } 0=\text { no })\end{array}$ & 0.357 & 0.479 & $0-1$ \\
\hline $\begin{array}{l}\text { Transportation rule violation } \\
\text { "Have you ever violated transportation rules?" }(1=\text { yes; } 0=\text { no })\end{array}$ & 0.431 & 0.495 & $0-1$ \\
\hline $1=$ affiliated with Islam, $0=$ others & 0.028 & 0.226 & $0-1$ \\
\hline $1=$ affiliated with Buddhism, $0=$ others & 0.054 & 0.164 & $0-1$ \\
\hline affiliated with Christianity, $0=$ others & 0.025 & 0.155 & $0-1$ \\
\hline Ethnicity $(1=$ non-Han ethnicity; 0 = Han ethnicity $)$ & 0.09 & 0.286 & $0-1$ \\
\hline Residence $(1=$ urban residence; $0=$ rural residence $)$ & 0.431 & 0.495 & $0-1$ \\
\hline Age (at the year of survey) & 48.838 & 15.497 & $19-98$ \\
\hline Female $(1=$ female; $0=$ male $)$ & 0.519 & 0.5 & $0-1$ \\
\hline $\begin{array}{l}\text { Education }(0=\text { no education; } 1=\text { elementary school; } 2=\text { middle school; } 3=\text { high } \\
\text { school; } 4=\text { adult high education; } 5=\text { college education and above })\end{array}$ & 1.971 & 1.338 & $0-5$ \\
\hline Married $(1=$ yes; $0=$ no $)$ & 0.81 & 0.393 & $0-1$ \\
\hline Unemployment $(1=$ yes; $0=$ no $)$ & 0.06 & 0.238 & $0-1$ \\
\hline Annual personal income (logged) & 8.037 & 3.184 & $0-14.845$ \\
\hline Communist party member $(1=$ yes; $0=$ no $)$ & 0.114 & 0.318 & $0-1$ \\
\hline \multicolumn{4}{|l|}{ Contextual Level } \\
\hline Number of mosques per 10,000 people & 0.239 & 1.44 & $0.0003-10.968$ \\
\hline Number of temples per 10,000 people & 0.147 & 0.144 & $0.0208-0.546$ \\
\hline Number of churches per 10,000 people & 0.141 & 0.195 & $0.001-1.125$ \\
\hline Total Population $(10,000$ people) & 0.032 & 0.02 & $0.001-075$ \\
\hline Percent of communist party members & 0.114 & 0.034 & $0.070-0.253$ \\
\hline GDP per capita $(10,000 \mathrm{RMB} \approx \mathrm{U} \$ 1500)$ & 2.564 & 1.015 & $1.030-4.460$ \\
\hline Urbanization rate & 46.873 & 8.687 & $29.890-63.400$ \\
\hline Theil index & 0.156 & 0.098 & $0.063-0.489$ \\
\hline Illiteracy rate & 7.201 & 3.276 & $3.200-15.940$ \\
\hline Percent of minor ethnicity & 8.672 & 12.858 & $0.310-59.430$ \\
\hline
\end{tabular}

10

8

6

4

2

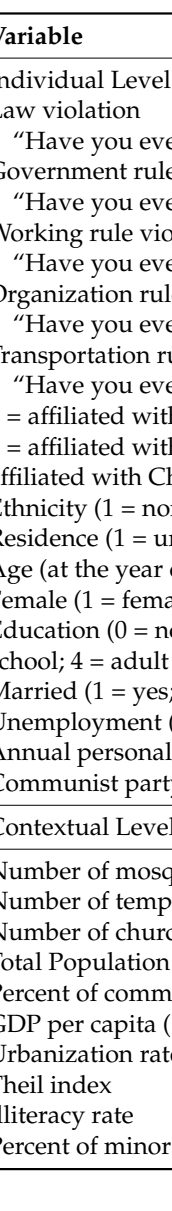

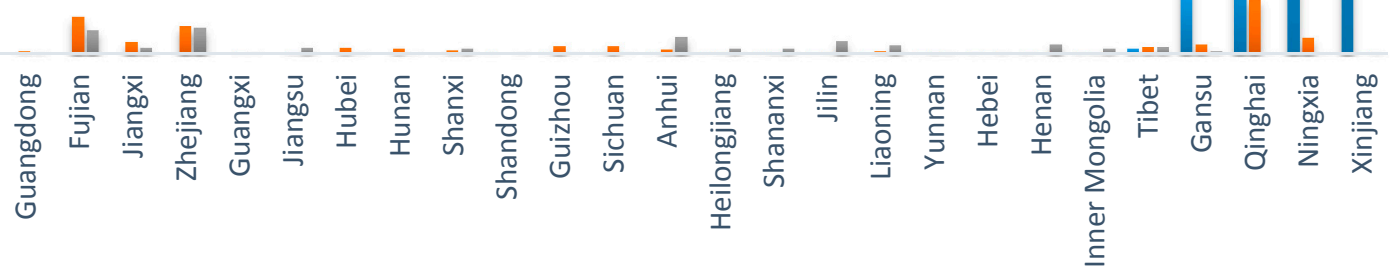

- mosques $\square$ temples $\square$ churches

Figure 1. Number of religious sites per 10,000 people in 25 provinces in China. 
Table 2 presents results from estimating multi-level models that include both the individual-level and provincial-level independent variables. Consistent with Hypothesis 1, respondents affiliated with Islam report lower odds of violating the law $(-0.666)$, workplace rules $(-0.498)$, and organizational rules $(-0.781)$ compared to those without a religious affiliation. However, the odds of violating transportation laws are not significantly lower for Muslims and the odds of violating government laws is only marginally significant $(-0.435, p=0.072)$. Buddhists also report lower odds of violating the law $(-0.245)$, workplace rules $(-0.256)$, government laws $(-0.292)$, and transportation laws $(-0.341)$, but are not different from religious nones in terms of their odds of violating organizational rules. Respondents affiliated with Christianity are not different from religious nones in the odds of all types of violations. In sum, contrary to previous findings that religion has no protective effect on deviance in China (Stark 2001; Zhang and Thomas 1994; Zhang and Xu 2007), we find some evidence that Islam and Buddhism, though not Christianity, have a deterrent effect on deviance in China. Thus, Hypothesis 1 received some support.

At the provincial level, the rate of mosques (i.e., number of mosques per 10,000 residents in the province) is negatively related with the odds of violating the law $(-0.155)$ and government rules and regulations $(-0.153)$, but not associated with the odds of violating workplace rules $(-0.101)$, organizational rules $(-0.094)$, and transportation laws $(-0.099)$. The rates of churches and temples had no significant relationship with the odds of any type of violation. Thus, empirical support for our second hypothesis is found only through Islam at a provincial level, but not through Christianity or Buddhism.

Sociodemographic variables are generally found to have significant relationships with law violations in the expected directions. For example, ethnic minority respondents report higher odds of violating the law and rules compared to their peers of Han ethnicity, which might have been due in part to their lack of assimilation into the Han-centric norms of China (Shahar and Weller 1996). Also, respondents of older age and higher socioeconomic status in terms of education and income are less likely to violate the law and various rules than those of younger age and lower socioeconomic status, with two exceptions, relationships between education and the government $(-0.024, p>0.05)$ and organizational rules $(-0.050, p>0.05)$. In addition, females are less likely to violate the organizational rule than males (-0.132), but Chinese males and females are no different in their odds of violating the laws and rules of the workplace, government, and transportation. Urban residents are less likely to commit violations than their non-urban counterparts, and unemployment is not related to law violations. Finally, respondents affiliated with the Communist Party are less likely to report deviance of all measures than those who are not Community Party members. At a provincial level, economic development (GDP per capita) is the only significant predictor of individual-level deviance, being inversely related to all but one law and rule violation, the exception being transportation rule violation $(-0.157, p>0.05)$.

To examine whether the individual-level religiosity's effect on law and rule violations is conditioned by provincial-level religiosity, Table 3 presents multi-level models that contain interactions between individual-level and province-level religiosity variables. In Table 3, we notice that the significance of the religiosity-deviance relationship at both individual and provincial levels remains almost the same as in Table 2. First, Muslims and Buddhists are less likely to report violations than religious nones, but Christians are no different from those with no religion. Second, at the provincial level, only Islam is significantly related to individual-level deviance in the expected, negative direction. Third, there is no significant cross-level interaction in predicting the odds of law and rule violations, with only one exception - there is a positive cross-level interaction between affiliation with Islam and the provincial level of mosques. That is, provincial-level Islam is found to weaken the deterrent effect of individual-level Islam on the violation of government laws instead of strengthening it, as expected in our third hypothesis. In sum, Hypothesis 3 failed to receive empirical support. 
Table 2. Religion as an individual and contextual control (individual $N=8224$; province $N=25$ ).

\begin{tabular}{|c|c|c|c|c|c|}
\hline & $\begin{array}{l}\text { (1) } \\
\text { Violating } \\
\text { the Law }\end{array}$ & $\begin{array}{c}\text { (2) Violating } \\
\text { Workplace } \\
\text { Rules }\end{array}$ & $\begin{array}{l}\text { (3) Violating } \\
\text { Government } \\
\text { Laws }\end{array}$ & $\begin{array}{l}\text { (4) Violating } \\
\text { Organizational } \\
\text { Rules }\end{array}$ & $\begin{array}{l}\text { (5) Violating } \\
\text { Transportation } \\
\text { Laws }\end{array}$ \\
\hline \multicolumn{6}{|l|}{ Individual level } \\
\hline Islam & $\begin{array}{c}-0.666^{*} \\
(0.263)\end{array}$ & $\begin{array}{c}-0.498^{*} \\
(0.236)\end{array}$ & $\begin{array}{l}-0.435 \\
(0.242)\end{array}$ & $\begin{array}{c}-0.781 \text { ** } \\
(0.257)\end{array}$ & $\begin{array}{l}-0.352 \\
(0.223)\end{array}$ \\
\hline Buddhism & $\begin{array}{c}-0.245 \text { * } \\
(0.119)\end{array}$ & $\begin{array}{c}-0.256^{*} \\
(0.112)\end{array}$ & $\begin{array}{c}-0.292 * \\
(0.114)\end{array}$ & $\begin{array}{l}-0.169 \\
(0.115)\end{array}$ & $\begin{array}{c}-0.341 \text { ** } \\
(0.110)\end{array}$ \\
\hline Christianity & $\begin{array}{l}-0.156 \\
(0.165)\end{array}$ & $\begin{array}{l}-0.110 \\
(0.156)\end{array}$ & $\begin{array}{c}-0.0116 \\
(0.154)\end{array}$ & $\begin{array}{c}-0.147 \\
(0.160) \\
\end{array}$ & $\begin{array}{l}-0.266 \\
(0.153)\end{array}$ \\
\hline Ethnic minority & $\begin{array}{c}0.481^{* * *} \\
(0.107)\end{array}$ & $\begin{array}{c}0.428^{* * *} \\
(0.107)\end{array}$ & $\begin{array}{c}0.415^{* * *} \\
(0.105)\end{array}$ & $\begin{array}{c}0.447^{* * *} \\
(0.108)\end{array}$ & $\begin{array}{c}0.365^{* * *} \\
(0.104)\end{array}$ \\
\hline Urban resident & $\begin{array}{c}-0.208^{* * *} \\
(0.062)\end{array}$ & $\begin{array}{c}-0.215^{* * *} \\
(0.060)\end{array}$ & $\begin{array}{c}-0.143 \text { * } \\
(0.060)\end{array}$ & $\begin{array}{c}-0.212^{* * *} \\
(0.061)\end{array}$ & $\begin{array}{c}-0.158 * * \\
(0.058)\end{array}$ \\
\hline Age & $\begin{array}{c}-0.008^{* * *} \\
(0.002)\end{array}$ & $\begin{array}{c}-0.008^{* * *} \\
(0.002)\end{array}$ & $\begin{array}{c}-0.010^{* * *} \\
(0.002)\end{array}$ & $\begin{array}{c}-0.008^{* * *} \\
(0.002)\end{array}$ & $\begin{array}{c}-0.007^{* * *} \\
(0.002)\end{array}$ \\
\hline Female & $\begin{array}{l}-0.103 \\
(0.053)\end{array}$ & $\begin{array}{l}-0.053 \\
(0.050)\end{array}$ & $\begin{array}{l}-0.076 \\
(0.050)\end{array}$ & $\begin{array}{c}-0.132 * \\
(0.052)\end{array}$ & $\begin{array}{l}-0.075 \\
(0.049)\end{array}$ \\
\hline Education & $\begin{array}{c}-0.069 * \\
(0.027)\end{array}$ & $\begin{array}{c}-0.085^{* *} \\
(0.026)\end{array}$ & $\begin{array}{l}-0.024 \\
(0.026)\end{array}$ & $\begin{array}{l}-0.050 \\
(0.026)\end{array}$ & $\begin{array}{c}-0.077^{* *} \\
(0.025)\end{array}$ \\
\hline Married & $\begin{array}{l}-0.034 \\
(0.066)\end{array}$ & $\begin{array}{c}-0.088 \\
(0.063)\end{array}$ & $\begin{array}{l}-0.094 \\
(0.063) \\
\end{array}$ & $\begin{array}{l}-0.070 \\
(0.064) \\
\end{array}$ & $\begin{array}{c}-0.108 \\
(0.061)\end{array}$ \\
\hline Unemployment & $\begin{array}{l}-0.191 \\
(0.109) \\
\end{array}$ & $\begin{array}{c}0.076 \\
(0.102) \\
\end{array}$ & $\begin{array}{c}0.114 \\
(0.101) \\
\end{array}$ & $\begin{array}{l}-0.015 \\
(0.104) \\
\end{array}$ & $\begin{array}{c}0.045 \\
(0.100) \\
\end{array}$ \\
\hline Income(logged) & $\begin{array}{c}-0.031^{* * *} \\
(0.008)\end{array}$ & $\begin{array}{c}-0.043^{* * *} \\
(0.008)\end{array}$ & $\begin{array}{c}-0.034^{* * *} \\
(0.008)\end{array}$ & $\begin{array}{c}-0.028^{* * *} \\
(0.008)\end{array}$ & $\begin{array}{c}-0.031^{* * *} \\
(0.008)\end{array}$ \\
\hline Communist party & $\begin{array}{c}-0.238 * * \\
(0.089) \\
\end{array}$ & $\begin{array}{c}-0.284^{* * *} \\
(0.083)\end{array}$ & $\begin{array}{c}-0.361 \text { *** } \\
(0.084)\end{array}$ & $\begin{array}{c}-0.398^{* * *} \\
(0.087)\end{array}$ & $\begin{array}{c}-0.227 \text { ** } \\
(0.080)\end{array}$ \\
\hline \multicolumn{6}{|l|}{ Contextual level } \\
\hline Number of mosques & $\begin{array}{c}-0.155^{*} \\
(0.064)\end{array}$ & $\begin{array}{l}-0.101 \\
(0.053) \\
\end{array}$ & $\begin{array}{c}-0.153 * * \\
(0.055)\end{array}$ & $\begin{array}{c}-0.094 \\
(0.065) \\
\end{array}$ & $\begin{array}{l}-0.099 \\
(0.055) \\
\end{array}$ \\
\hline Number of temples & $\begin{array}{c}0.007 \\
(0.532)\end{array}$ & $\begin{array}{c}0.375 \\
(0.449)\end{array}$ & $\begin{array}{c}0.253 \\
(0.455)\end{array}$ & $\begin{array}{c}-0.176 \\
(0.567)\end{array}$ & $\begin{array}{c}0.217 \\
(0.492)\end{array}$ \\
\hline Number of churches & $\begin{array}{c}0.215 \\
(0.779) \\
\end{array}$ & $\begin{array}{l}-0.363 \\
(0.655)\end{array}$ & $\begin{array}{l}-0.420 \\
(0.664) \\
\end{array}$ & $\begin{array}{c}0.192 \\
(0.826) \\
\end{array}$ & $\begin{array}{l}-0.068 \\
(0.714) \\
\end{array}$ \\
\hline Population density & $\begin{array}{l}-1.311 \\
(6.574) \\
\end{array}$ & $\begin{array}{l}-0.358 \\
(5.591) \\
\end{array}$ & $\begin{array}{c}0.865 \\
(5.661) \\
\end{array}$ & $\begin{array}{l}0.0623 \\
(6.986) \\
\end{array}$ & $\begin{array}{l}-3.836 \\
(6.086) \\
\end{array}$ \\
\hline $\begin{array}{l}\text { Percent Communist Party } \\
\text { members }\end{array}$ & $\begin{array}{c}2.400 \\
(2.736) \\
\end{array}$ & $\begin{array}{c}2.509 \\
(2.328) \\
\end{array}$ & $\begin{array}{c}2.373 \\
(2.354) \\
\end{array}$ & $\begin{array}{c}2.879 \\
(2.926)\end{array}$ & $\begin{array}{l}2.386 \\
(2.556) \\
\end{array}$ \\
\hline GDP per capita $(10,000 \mathrm{RMB})$ & $\begin{array}{c}-0.401 * \\
(0.202)\end{array}$ & $\begin{array}{c}-0.347^{*} \\
(0.172)\end{array}$ & $\begin{array}{c}-0.357 * \\
(0.174)\end{array}$ & $\begin{array}{c}-0.422 * \\
(0.214)\end{array}$ & $\begin{array}{l}-0.157 \\
(0.187)\end{array}$ \\
\hline Urbanization rate & $\begin{array}{c}0.036 \\
(0.028) \\
\end{array}$ & $\begin{array}{c}0.024 \\
(0.024) \\
\end{array}$ & $\begin{array}{c}0.036 \\
(0.024) \\
\end{array}$ & $\begin{array}{c}0.034 \\
(0.030) \\
\end{array}$ & $\begin{array}{l}-0.002 \\
(0.026)\end{array}$ \\
\hline Theil index & $\begin{array}{l}-0.239 \\
(1.169) \\
\end{array}$ & $\begin{array}{c}0.268 \\
(0.992) \\
\end{array}$ & $\begin{array}{c}0.151 \\
(1.003) \\
\end{array}$ & $\begin{array}{l}-0.233 \\
(1.246) \\
\end{array}$ & $\begin{array}{c}1.221 \\
(1.085) \\
\end{array}$ \\
\hline Illiteracy rate & $\begin{array}{l}-0.050 \\
(0.038) \\
\end{array}$ & $\begin{array}{l}-0.034 \\
(0.032) \\
\end{array}$ & $\begin{array}{l}-0.025 \\
(0.032)\end{array}$ & $\begin{array}{l}-0.046 \\
(0.040)\end{array}$ & $\begin{array}{l}-0.046 \\
(0.035)\end{array}$ \\
\hline Percent of ethnic minority & $\begin{array}{c}0.002 \\
(0.008) \\
\end{array}$ & $\begin{array}{l}-0.000 \\
(0.007) \\
\end{array}$ & $\begin{array}{c}0.004 \\
(0.007) \\
\end{array}$ & $\begin{array}{l}-0.002 \\
(0.009)\end{array}$ & $\begin{array}{c}0.001 \\
(0.007) \\
\end{array}$ \\
\hline Intercept & $\begin{array}{l}-0.400 \\
(1.114)\end{array}$ & $\begin{array}{c}0.401 \\
(0.945) \\
\end{array}$ & $\begin{array}{l}-0.493 \\
(0.958)\end{array}$ & $\begin{array}{l}-0.156 \\
(1.184)\end{array}$ & $\begin{array}{c}1.135 \\
(1.033) \\
\end{array}$ \\
\hline ICC & $3.43 \%$ & $2.42 \%$ & $2.48 \%$ & $4.01 \%$ & $3.05 \%$ \\
\hline
\end{tabular}

Note: standardized error in parentheses; ${ }^{* * *} p<0.001,{ }^{* *} p<0.01,{ }^{*} p<0.05$. 
Table 3. Religion as an individual and contextual control, with cross-level interaction (individual $N=8224$; province $N=25$ ).

\begin{tabular}{|c|c|c|c|c|c|}
\hline & $\begin{array}{l}\text { (1) Violating } \\
\text { the Law }\end{array}$ & $\begin{array}{l}\text { (2) Violating } \\
\text { Workplace } \\
\text { Rules }\end{array}$ & $\begin{array}{c}\text { (3) Violating } \\
\text { Government } \\
\text { Laws }\end{array}$ & $\begin{array}{c}\text { (4) Violating } \\
\text { Organizational } \\
\text { Rules }\end{array}$ & $\begin{array}{c}\text { (5) Violating } \\
\text { Transportation } \\
\text { Laws }\end{array}$ \\
\hline \multicolumn{6}{|l|}{ Individual level } \\
\hline Islam (A) & $\begin{array}{c}-0.904^{* *} \\
(0.292)\end{array}$ & $\begin{array}{c}-0.677^{* *} \\
(0.260)\end{array}$ & $\begin{array}{c}-0.686 * \\
(0.267)\end{array}$ & $\begin{array}{c}-1.000^{* * *} \\
(0.286)\end{array}$ & $\begin{array}{l}-0.354 \\
(0.243)\end{array}$ \\
\hline Buddhism (B) & $\begin{array}{l}-0.263 \\
(0.159)\end{array}$ & $\begin{array}{c}-0.368 * \\
(0.149)\end{array}$ & $\begin{array}{c}-0.402 \text { ** } \\
(0.151)\end{array}$ & $\begin{array}{l}-0.111 \\
(0.151)\end{array}$ & $\begin{array}{c}-0.442 \text { ** } \\
(0.146)\end{array}$ \\
\hline Christianity $(\mathrm{C})$ & $\begin{array}{l}-0.418 \\
(0.278)\end{array}$ & $\begin{array}{l}-0.144 \\
(0.260)\end{array}$ & $\begin{array}{l}-0.213 \\
(0.257)\end{array}$ & $\begin{array}{l}-0.388 \\
(0.271)\end{array}$ & $\begin{array}{l}-0.276 \\
(0.254)\end{array}$ \\
\hline Ethnic minority & $\begin{array}{c}0.483^{* * *} \\
(0.107)\end{array}$ & $\begin{array}{c}0.429 * * * \\
(0.107)\end{array}$ & $\begin{array}{c}0.414^{* * *} \\
(0.106)\end{array}$ & $\begin{array}{c}0.452 * * * \\
(0.108)\end{array}$ & $\begin{array}{c}0.364^{* * *} \\
(0.104)\end{array}$ \\
\hline Urban resident & $\begin{array}{c}-0.207^{* * *} \\
(0.062)\end{array}$ & $\begin{array}{c}-0.214^{* * *} \\
(0.060)\end{array}$ & $\begin{array}{c}-0.142 \text { * } \\
(0.060)\end{array}$ & $\begin{array}{c}-0.210 * * * \\
(0.061)\end{array}$ & $\begin{array}{c}-0.159 * * \\
(0.058)\end{array}$ \\
\hline Age & $\begin{array}{l}-0.008^{* * *} \\
(0.002)\end{array}$ & $\begin{array}{l}-0.008^{* * *} \\
(0.002)\end{array}$ & $\begin{aligned}-0.010^{* * *} & (0.002)\end{aligned}$ & $\begin{array}{l}-0.008^{* * *} \\
(0.002)\end{array}$ & $\begin{array}{c}-0.007^{* * *} \\
(0.001)\end{array}$ \\
\hline Female & $\begin{array}{l}-0.102 \\
(0.053)\end{array}$ & $\begin{array}{c}-0.0515 \\
(0.050)\end{array}$ & $\begin{array}{c}-0.0742 \\
(0.050)\end{array}$ & $\begin{array}{c}-0.131 \text { * } \\
(0.052)\end{array}$ & $\begin{array}{l}-0.074 \\
(0.049)\end{array}$ \\
\hline Education & $\begin{array}{c}-0.067 * \\
(0.027)\end{array}$ & $\begin{array}{c}-0.084 * * \\
(0.026)\end{array}$ & $\begin{array}{l}-0.022 \\
(0.026)\end{array}$ & $\begin{array}{l}-0.049 \\
(0.026)\end{array}$ & $\begin{array}{c}-0.078^{* *} \\
(0.025)\end{array}$ \\
\hline Married & $\begin{array}{l}-0.033 \\
(0.066)\end{array}$ & $\begin{array}{l}-0.088 \\
(0.063)\end{array}$ & $\begin{array}{l}-0.093 \\
(0.063)\end{array}$ & $\begin{array}{l}-0.070 \\
(0.064)\end{array}$ & $\begin{array}{l}-0.108 \\
(0.061)\end{array}$ \\
\hline Unemployment & $\begin{array}{l}-0.193 \\
(0.109)\end{array}$ & $\begin{array}{l}0.076 \\
(0.102)\end{array}$ & $\begin{array}{c}0.112 \\
(0.101)\end{array}$ & $\begin{array}{l}-0.015 \\
(0.104)\end{array}$ & $\begin{array}{c}0.044 \\
(0.100)\end{array}$ \\
\hline Income(logged) & $\begin{array}{c}-0.030 * * * \\
(0.008)\end{array}$ & $\begin{array}{c}-0.043^{* * *} \\
(0.008)\end{array}$ & $\begin{array}{c}-0.034^{* * *} \\
(0.008)\end{array}$ & $\begin{array}{c}-0.028^{* * *} \\
(0.008)\end{array}$ & $\begin{array}{c}-0.031^{* * *} \\
(0.008)\end{array}$ \\
\hline Communist party & $\begin{array}{c}-0.236 * * \\
(0.089)\end{array}$ & $\begin{array}{c}-0.282 * * * \\
(0.083)\end{array}$ & $\begin{array}{c}-0.359 * * * \\
(0.084)\end{array}$ & $\begin{array}{c}-0.395^{* * *} \\
(0.087)\end{array}$ & $\begin{array}{c}-0.227^{* *} \\
(0.080)\end{array}$ \\
\hline \multicolumn{6}{|l|}{ Contextual level } \\
\hline Rate of mosques (D) & $\begin{array}{c}-0.609 * \\
(0.263)\end{array}$ & $\begin{array}{l}-0.219 * \\
(0.0940)\end{array}$ & $\begin{array}{c}-0.543^{* *} \\
(0.204)\end{array}$ & $\begin{array}{l}-0.320 \\
(0.168)\end{array}$ & $\begin{array}{c}-0.100 \\
(0.0677)\end{array}$ \\
\hline Rate of temples (E) & $\begin{array}{c}0.420 \\
(0.502)\end{array}$ & $\begin{array}{c}0.451 \\
(0.430)\end{array}$ & $\begin{array}{c}0.580 \\
(0.426)\end{array}$ & $\begin{array}{l}0.0423 \\
(0.535)\end{array}$ & $\begin{array}{c}0.191 \\
(0.492)\end{array}$ \\
\hline Rate of churches $(\mathrm{F})$ & $\begin{array}{l}-0.430 \\
(0.738) \\
\end{array}$ & $\begin{array}{l}-0.529 \\
(0.626)\end{array}$ & $\begin{array}{c}-0.972 \\
(0.618)\end{array}$ & $\begin{array}{c}-0.117 \\
(0.780)\end{array}$ & $\begin{array}{c}-0.089 \\
(0.713) \\
\end{array}$ \\
\hline Total population & $\begin{array}{l}-3.589 \\
(5.613)\end{array}$ & $\begin{array}{l}-0.978 \\
(5.293)\end{array}$ & $\begin{array}{l}-1.173 \\
(4.892)\end{array}$ & $\begin{array}{l}-1.266 \\
(6.408)\end{array}$ & $\begin{array}{l}-3.833 \\
(6.067)\end{array}$ \\
\hline $\begin{array}{l}\text { Percent of Communist Party } \\
\text { member }\end{array}$ & $\begin{array}{l}3.610 \\
(2.337)\end{array}$ & $\begin{array}{c}2.831 \\
(2.199)\end{array}$ & $\begin{array}{c}3.397 \\
(2.029)\end{array}$ & $\begin{array}{c}3.524 \\
(2.682)\end{array}$ & $\begin{array}{c}2.394 \\
(2.548)\end{array}$ \\
\hline GDP per capita (10,000 RMB) & $\begin{array}{c}-0.410 * \\
(0.169)\end{array}$ & $\begin{array}{c}-0.350 * \\
(0.163)\end{array}$ & $\begin{array}{c}-0.366 \text { * } \\
(0.148)\end{array}$ & $\begin{array}{c}-0.418 * \\
(0.195)\end{array}$ & $\begin{array}{c}-0.160 \\
(0.186)\end{array}$ \\
\hline Urbanization rate & $\begin{array}{c}0.038 \\
(0.023)\end{array}$ & $\begin{array}{c}0.025 \\
(0.022)\end{array}$ & $\begin{array}{c}0.039 \\
(0.020)\end{array}$ & $\begin{array}{c}0.034 \\
(0.027)\end{array}$ & $\begin{array}{l}-0.002 \\
(0.026)\end{array}$ \\
\hline Theil index & $\begin{array}{l}-0.146 \\
(0.965)\end{array}$ & $\begin{array}{c}0.332 \\
(0.933)\end{array}$ & $\begin{array}{c}0.253 \\
(0.841)\end{array}$ & $\begin{array}{l}-0.160 \\
(1.128)\end{array}$ & $\begin{array}{c}1.233 \\
(1.081)\end{array}$ \\
\hline Illiteracy rate & $\begin{array}{l}-0.025 \\
(0.034) \\
\end{array}$ & $\begin{array}{c}-0.028 \\
(0.030) \\
\end{array}$ & $\begin{array}{c}-0.0036 \\
(0.029)\end{array}$ & $\begin{array}{c}-0.034 \\
(0.037) \\
\end{array}$ & $\begin{array}{l}-0.045 \\
(0.035) \\
\end{array}$ \\
\hline Percent of ethnic minority & $\begin{array}{l}-0.000 \\
(0.007)\end{array}$ & $\begin{array}{l}-0.001 \\
(0.007)\end{array}$ & $\begin{array}{c}0.002 \\
(0.006)\end{array}$ & $\begin{array}{l}-0.004 \\
(0.008)\end{array}$ & $\begin{array}{c}0.001 \\
(0.008)\end{array}$ \\
\hline \multicolumn{6}{|l|}{ Cross-level Interaction } \\
\hline$A \times D$ & $\begin{array}{c}0.505 \\
(0.269)\end{array}$ & $\begin{array}{c}0.155 \\
(0.094)\end{array}$ & $\begin{array}{l}0.441^{*} \\
(0.209)\end{array}$ & $\begin{array}{c}0.272 \\
(0.168)\end{array}$ & $\begin{array}{c}0.00189 \\
(0.058)\end{array}$ \\
\hline $\mathrm{B} \times \mathrm{E}$ & $\begin{array}{c}0.091 \\
(0.504)\end{array}$ & $\begin{array}{c}0.538 \\
(0.463)\end{array}$ & $\begin{array}{c}0.525 \\
(0.459)\end{array}$ & $\begin{array}{c}-0.284 \\
(0.499)\end{array}$ & $\begin{array}{c}0.471 \\
(0.445)\end{array}$ \\
\hline $\mathrm{C} \times \mathrm{F}$ & $\begin{array}{c}1.413 \\
(1.171)\end{array}$ & $\begin{array}{c}0.197 \\
(1.171)\end{array}$ & $\begin{array}{c}1.117 \\
(1.113)\end{array}$ & $\begin{array}{c}1.318 \\
(1.168)\end{array}$ & $\begin{array}{c}0.055 \\
(1.128)\end{array}$ \\
\hline Intercept & $\begin{array}{l}-0.681 \\
(0.943)\end{array}$ & $\begin{array}{c}0.342 \\
(0.892)\end{array}$ & $\begin{array}{l}-0.724 \\
(0.819)\end{array}$ & $\begin{array}{l}-0.261 \\
(1.078)\end{array}$ & $\begin{array}{c}1.129 \\
(1.029)\end{array}$ \\
\hline ICC & $2.17 \%$ & $2.09 \%$ & $1.60 \%$ & $3.21 \%$ & $3.02 \%$ \\
\hline
\end{tabular}




\section{Discussion and Conclusions}

This study examined the effect of religion, measured at both individual and contextual level, on an individual's deviant behaviors in China, where religion is regulated and marginalized (Grim and Finke 2006; Grim and Finke 2007; Yang 2006, 2011). By doing so, we tested the moral community thesis in a non-Western context, which has rarely been done since it was proposed by Stark (Adamczyk 2008; Regnerus 2003; Stark 1996; Wallace et al. 2007; Welch et al. 1991). Previous tests conducted in the U.S. context show inconsistent results regarding whether contextual religiosity is inversely related to individual deviance or enhances the inverse relationship between individual religiosity and deviance.

The present study found mixed support for the moral community thesis. That is, consistent with Stark's argument that religiosity is a group or communal property that influences an individual's behaviors (Stark 1996; Stark et al. 1982), provincial-level Islam tended to be inversely related to violations of the law and various rules. This is also consistent with previous research that homogeneous religion rather than overall religiosity protects individuals from deviance (Ellison et al. 1997; Regnerus 2003; Trawick and Howsen 2006).

However, provincial-level Christianity and Buddhism were not related to individual-level deviance. Furthermore, non-significant cross-level interactions provided no support for Stark's proposition that the effect of individual religiosity on deviance is larger or more likely to be observed in a more religious than in a less or non-religious context (Stark 1996; Stark et al. 1982). The only significant cross-level interactions between the individual-level effect of Islam and provincial-level Islam on deviance was in the opposite direction-positive, which indicates that Muslims living in provinces that have a relatively large number of mosques were less likely to report violating government rules and regulations than those living in provinces with a small number of mosques.

While it is difficult to fully explain this unexpected finding, we suspect that the positive cross-level interactions might be to do with the unique circumstances of Islam in China, particularly given that the unexpected relationship was found only for violation of government laws. Although it is a strong institutional religion, Islam is not deeply embedded in the mainstream Han-dominated Chinese culture and has had conflicts and strained relationships with the Chinese government. In such a context, as provincial-level Islam strengthens, it might contribute to anti-government sentiment among Muslims and even create an alternative authority out of resistance to the government in Islam-dominated provinces. As a result, the individual-level deterrent effect of Islam on the violation of government rules and regulations might weaken as the provincial level of anti-government Islamic culture strengthens. Although this finding is inconsistent with the moral community thesis in terms of direction, it is consistent with the thesis in that it shows contextual-level religion moderating the effect of individual-level religion on deviance, which might have to do with the history and status of Islam in China.

We also speculate that the non-significant effect of both individual-level and provincial-level Christianity on deviance might be attributable to the fact that the Christian population is widely spread across Chinese provinces, unlike Muslims, which are concentrated in northwestern provinces. Thus, it is harder to shape a strong moral community that exerts a deterrent effect on Christians. If Christians were as concentrated in some provinces as Muslims, we might have observed a provincial-level effect of Christianity on deviance. Similarly, the protective effect of Buddhism might have been observed only at an individual level, not at a provincial level or in cross-level interaction, perhaps because Buddhists are widely spread across Chinese provinces. Besides the lack of geographic concentration of Christians and Buddhists in China, another reason for failing to find an effect of provincial-level Christianity and Buddhism might be the limited measurement: that is, if we used the proportion of Christians and Buddhists in the province, consistent with Stark's discussion of the moral community thesis, we might have found different results. Future research should explore whether these speculations have any merit. 
The present findings also suggest other research topics for future research. First, we could not examine the individual and contextual effect of folk religions because no information about religious sites for folk religion was available in our data, while a previous study shows that folk religions can provide public goods and shaping local democracy for local community (Tsai 2007). Further research needs to measure the regional, provincial, and communal level of folk religiosity to examine the effect of context-level folk religiosity by taking two approaches to data collection. Specifically, the percentage of people who identify themselves with folk religion can be calculated for each province based on survey data. It should be kept in mind, however, that this percentage may be underestimated since many followers of folk religions do not necessarily report that they are affiliated with a particular folk religion despite practicing them (Palmer and Wickeri 2011). Alternatively, religious sites of folk religions, such as ancestor halls and temples of various deities, can be used as an indicator of folk religiosity in contextual level.

Second, further studies are needed to incorporate the thriving underground churches into the study of aggregate-level religiosity. Because the Spatial Explorer of Religion data include only officially registered religious sites, the number of total religious sites is surely an underestimate given that unregistered house churches and small-scale congregations are thriving in both urban and rural China (Bao et al. 2014; Wenger 2004; Yang 2005, 2010; Yu 2010). Cults with strong organization, such as Eastern Lightning and Falungong, that are forbidden by the government should also be taken into account (Chan 2004; Dunn 2008).

Additionally, future research on religion in China should examine the religion-deviance relationship using other common but culture-appropriate measures of both constructs. That is, researchers should test the moral community thesis using ascetic (e.g., substance use) as well as anti-ascetic deviance (e.g., law violation). They should also consider types of deviance particularly recognized by Chinese society (e.g., extramarital sexuality and lack of filial piety). Common measures of religiosity, such as religious salience and practices, should be examined as well. However, church attendance may not be a very good indicator of religiosity because Eastern religions (e.g., Zen Buddhism and Taoism) encourage private rather than public practice of religion, unlike Abrahamic religions, which emphasize frequent attendance at communal religious activities. In addition, religious attendance is suppressed as government regulation increases the risks and costs of public attendance (Hu 2013; Yang 2006).

Finally, further research is needed to examine the effect of religiosity at lower levels than the province, such as community, county, and village. While we found province-level religiosity to affect individual deviant behaviors, within-province variations in religiosity are worth studying given that not only religiosity but also economic development and historical characteristics related to religion would vary across counties and villages (Cai et al. 2002; Palmer and Wickeri 2011; Tsai 2007).

In conclusion, despite the limitations acknowledged above, our study partially supports the moral community thesis by finding Islam is inversely related to individual deviance at both an individual and a provincial level. Although no significant provincial influences of Buddhism and Christianity on deviance are found, we speculate that Buddhism and Christianity are not powerful enough to shape a strong moral community due to their lower religious populations and being more spread out geographically.

Author Contributions: X.W. and S.J.J. jointly developed the concepts and designed the study. X.W. drafted the literature review, analyzed the data and interpreted the results. S.J.J. supervised the research, improved literature review and opened the discussion for the research.

Funding: This study received no funding or grant.

Ethical Approval: This article does not contain any studies with human participants or animals performed by any of the authors.

Conflicts of Interest: The authors declare no conflict of interest. 


\section{References}

Adamczyk, Amy. 2008. The Effects of Religious Contextual Norms, Structural Constraints, and Personal Religiosity on Abortion Decisions. Social Science Research 37: 657-72. [CrossRef] [PubMed]

Adamczyk, Amy, and Brittany E. Hayes. 2012. Religion and Sexual Behaviors Understanding the Influence of Islamic Cultures and Religious Affiliation for Explaining Sex Outside of Marriage. American Sociological Review 77: 723-46. [CrossRef]

Albrecht, Stan L., Bruce A. Chadwick, and David S. Alcorn. 1977. Religiosity and Deviance: Application of an Attitude-Behavior Contingent Consistency Model. Journal for the Scientific Study of Religion 16: 263-74. [CrossRef]

Bahr, Stephen J., and John P. Hoffmann. 2008. Religiosity, Peers, and Adolescent Drug Use. Journal of Drug Issues 38: 743-69. [CrossRef]

Baier, Colin J., and Bradley R. E. Wright. 2001. 'If You Love Me, Keep My Commandments': A Meta-Analysis of the Effect of Religion on Crime. Journal of Research in Crime and Delinquency 38: 3-21. [CrossRef]

Bao, Shuming, Changzhen Wang, and Miao Shui. 2014. Spatial Study of Religion with Spatial Religion Explorer. Paper presented at 2014 22nd International Conference on Geoinformatics, Kaohsiung, Taiwan, June 25-27; pp. 1-8.

Benda, Brent B. 2002. Religion and Violent Offenders in Boot Camp: A Structural Equation Model. Journal of Research in Crime and Delinquency 39: 91-121. [CrossRef]

Benda, Brent B., and Robert Flynn Corwyn. 2001. Are the Effects of Religion on Crime Mediated, Moderated, and Misrepresented by Inappropriate Measures? Journal of Social Service Research 27: 57-86. [CrossRef]

Burkett, Steven R., and Mervin White. 1974. Hellfire and Delinquency: Another Look. Journal for the Scientific Study of Religion 13: 455-62. [CrossRef]

Cai, Fang, Dewen Wang, and Yang Du. 2002. Regional Disparity and Economic Growth in China: The Impact of Labor Market Distortions. China Economic Review 13: 197-212. [CrossRef]

Cao, Shixiong. 2012. Socioeconomic Value of Religion and the Impacts of Ideological Change in China. Economic Modelling 29: 2621-26. [CrossRef]

Chan, Cheris Shun-ching. 2004. The Falun Gong in China: A Sociological Perspective. The China Quarterly 179: 665-83. [CrossRef]

Chen, Hsinchih. 1995. The Development of Taiwanese Folk Religion, 1683-1945. Ph.D. dissertation, University of Washington, Seattle, WA, USA, May 31. Available online: https://digital.lib.washington.edu:443/ researchworks/handle/1773/8853 (accessed on 12 November 2017).

Cochran, John K., and Ronald L. Akers. 1989. Beyond Hellfire: An Exploration of the Variable Effects of Religiosity on Adolescent Marijuana and Alcohol Use. Journal of Research in Crime and Delinquency 26: 198-225. [CrossRef]

Cochran, John K., Peter B. Wood, and Bruce J. Arneklev. 1994. Is the Religiosity-Delinquency Relationship Spurious? A Test of Arousal and Social Control Theories. Journal of Research in Crime and Delinquency 31: 92-123. [CrossRef]

Corcoran, Katie E., David Pettinicchio, and Blaine Robbins. 2012. Religion and the Acceptability of White-Collar Crime: A Cross-National Analysis. Journal for the Scientific Study of Religion 51: 542-67. [CrossRef]

Creel, Herrlee Glessner. 1932. Was Confucius Agnostic? T'oung Pao 29: 55-99. [CrossRef]

Davis, Elizabeth Van Wie. 2008. Uyghur Muslim Ethnic Separatism in Xinjiang, China. Asian Affairs: An American Review 35: 15-30. [CrossRef]

Dean, Kenneth. 2003. Local Communal Religion in Contemporary South-East China. The China Quarterly 174: 338-58. [CrossRef]

Dunn, Emily C. 2008. 'Cult,'Church, and the CCP: Introducing Eastern Lightning. Modern China 35: 96-119. [CrossRef]

Durkheim, Emile. 1926. The Elementary Forms of the Religious Life a Study in Religious Sociology. Crows Nest: Allen \& Unwin.

Durkheim, Émile. 1976. The Elementary Forms of the Religious Life. Formes Élémentaires de La Vie religieuse. English. London: Allen and Unwin.

Ellis, Lee. 1987. Religiosity and Criminality from the Perspective of Arousal Theory. Journal of Research in Crime and Delinquency 24: 215-32. [CrossRef] 
Ellis, Lee, and James Peterson. 1996. Crime and Religion: An International Comparison among Thirteen Industrial Nations. Personality and Individual Differences 20: 761-68. [CrossRef]

Ellison, Christopher G., Jeffrey A. Burr, and Patricia L. McCall. 1997. Religious Homogeneity and Metropolitan Suicide Rates. Social Forces 76: 273-99. [CrossRef]

Feuchtwang, Stephan. 2010. The Anthropology of Religion, Charisma, and Ghosts: Chinese Lessons for Adequate Theory. Berlin: Walter de Gruyter.

Finke, Roger, and Amy Adamczyk. 2008. Cross-National Moral Beliefs: The Influence of National Religious Context. Sociological Quarterly 49: 617-52. [CrossRef] [PubMed]

Finke, Roger, and Rodney Stark. 2005. The Churching of America, 1776-2005: Winners and Losers in Our Religious Economy. New Brunswick: Rutgers University Press.

Gladney, Dru C. 1996. Muslim Chinese: Ethnic Nationalism in the People's Republic. Cambridge: Harvard Univ Asia Center.

Grim, Brian J., and Roger Finke. 2006. International Religion Indexes: Government Regulation, Government Favoritism, and Social Regulation of Religion. Interdisciplinary Journal of Research on Religion 2. Available online: http:/ / www.ncbi.nlm.nih.gov/pmc/articles/PMC4254791/ (accessed on 12 November 2017).

Grim, Brian J., and Roger Finke. 2007. Religious Persecution in Cross-National Context: Clashing Civilizations or Regulated Religious Economies? American Sociological Review 72: 633-58. [CrossRef]

Groves, W. Byron, Graeme Newman, and Charles Corrado. 1987. Islam, Modernization and Crime: A Test of the Religious Ecology Thesis. Journal of Criminal Justice 15: 495-503. [CrossRef]

Hafez, Mohammed M. 2004. From Marginalization to Massacres: Explaining GIA Violence in Algeria. In Islamic Activism: A Social Movement Theory Approach. Bloomington: Indiana University Press, pp. 37-54.

Heaton, Paul. 2006. Does Religion Really Reduce Crime? Journal of Law and Economics 49: 147-72. [CrossRef]

Higgins, Paul C., and Gary L. Albrecht. 1977. Hellfire and Delinquency Revisited. Social Forces 55: 952-58. [CrossRef]

Hirschi, Travis, and Rodney Stark. 1969. Hellfire and Delinquency. Social Problems 17: 202-13. [CrossRef]

Hu, Anning. 2013. Generalized Trust among Christians in Urban China: Analysis Based on Propensity Score Matching. Current Sociology 61: 1021-39. [CrossRef]

Jensen, Gary F, and L. Erickson Maynard. 1979. The Religous Factor and Delinquency: Another Look at the Hellfire Hypothesis. The Religous Dimension: New Directions in Quantitative Research 3: 157-77.

Johnson, Byron R. 1987. Religiosity and Institutional Deviance: The Impact of Religious Variables upon Inmate Adjustment. Criminal Justice Review 12: 21. [CrossRef]

Johnson, Byron, and Sung Joon Jang. 2011. Crime and Religion: Accessing the Role of the Faith Factor. In Comtemporary Issues in Criminological Theory and Research: The Role of Social Institution. Belmont: Wadsworth, pp. 117-50.

Johnson, Byron R., Sung Joon Jang, Spencer De Li, and David Larson. 2000. The 'Invisible Institution' and Black Youth Crime: The Church as an Agency of Local Social Control. Journal of Youth and Adolescence 29: 479-98. [CrossRef]

Junger, Marianne, and Wim Polder. 1993. Religiosity, Religious Climate, and Delinquency among Ethnic Groups in the Netherlands. British Journal of Criminology 33: 416-35. [CrossRef]

Koesel, Karrie J. 2014. Religion and Authoritarianism: Cooperation, Conflict, and the Consequences. Cambridge: Cambridge University Press.

Lee, Matthew R. 2006. The Religious Institutional Base and Violent Crime in Rural Areas. Journal for the Scientific Study of Religion 45: 309-24. [CrossRef]

Lee, Matthew R., and John P. Bartkowski. 2004. Love Thy Neighbor? Moral Communities, Civic Engagement, and Juvenile Homicide in Rural Areas. Social Forces 82: 1001-35. [CrossRef]

Lu, Feng, and Jianhua Xu. 2004. Regional Economic Disparity in China: Empirical Analysis on Gini Index and Theil Index. Research on Cooperation between East and West in China 1: 60-85.

Madsen, Richard. 1998. China's Catholics: Tragedy and Hope in an Emerging Civil Society. Berkeley: University of California Press.

Maimon, David, and Danielle C. Kuhl. 2008. Social Control and Youth Suicidality: Situating Durkheim's Ideas in a Multilevel Framework. American Sociological Review 73: 921-43. [CrossRef] 
Marsiglia, Flavio Francisco, Stephen Kulis, Tanya Nieri, and Monica Parsai. 2005. God Forbid! Substance Use among Religious and Nonreligious Youth. American Journal of Orthopsychiatry 75: 585-98. [CrossRef] [PubMed]

Olson, John Kevin. 1990. Crime and Religion: A Denominational and Community Analysis. Journal for the Scientific Study of Religion 29: 395-403. [CrossRef]

Ovadia, Seth, and Laura M. Moore. 2010. Decomposing the Moral Community: Religious Contexts and Teen Childbearing. City \& Community 9: 320-34.

Palmer, David A., and Philip L. Wickeri. 2011. Chinese Religious Life. New York: Oxford University Press.

Potter, Pitman B. 2003. Belief in Control: Regulation of Religion in China. The China Quarterly 174: $317-37$. [CrossRef]

Raudenbush, Stephen W., Bryk Anthony, Fai Cheong Yuk, and Congdon Richard. 2004. HLM 6: Hierarchical Linear and Nonlinear Modeling. Lincolnwood: Scientific Software International.

Regnerus, Mark D. 2003. Moral Communities and Adolescent Delinquency. Sociological Quarterly 44: 523-54. [CrossRef]

Rhodes, Albert Lewis, and Albert J. Reiss. 1970. The Religious Factor and Delinquent Behavior. Journal of Research in Crime and Delinquency 7: 83-98. [CrossRef]

Scheepers, Peer, Manfred Te Grotenhuis, and Frans Van Der Slik. 2002. Education, Religiosity and Moral Attitudes: Explaining Cross-National Effect Differences. Sociology of Religion 63: 157-76. [CrossRef]

Shahar, Meir, and Robert Paul Weller. 1996. Unruly Gods: Divinity and Society in China. Honolulu: University of Hawaii Press.

Sloane, Douglas M., and Raymond H. Potvin. 1986. Religion and Delinquency: Cutting Through the Maze. Social Forces 65: 87-105. [CrossRef]

Stack, Steven, and Augustine J. Kposowa. 2011. Religion and Suicide Acceptability: A Cross-National Analysis. Journal for the Scientific Study of Religion 50: 289-306. [CrossRef] [PubMed]

Stark, Rodney. 1996. Religion as Context: Hellfire and Delinquency One More Time. Sociology of Religion 57: 163-73. [CrossRef]

Stark, Rodney. 2001. Gods, Rituals, and the Moral Order. Journal for the Scientific Study of Religion 40: 619-36. [CrossRef]

Stark, Rodney, Lori Kent, and Daniel P. Doyle. 1982. Religion and Delinquency: The Ecology of a 'Lost' Relationship. Journal of Research in Crime and Delinquency 19: 4-24. [CrossRef]

Stark, Rodney, and Xiuhua Wang. 2015. A Star in the East: The Rise of Christianity in China, 1st ed. West Conshohocken: Templeton Press.

Sturgis, Paul W., and Robert D. Baller. 2012. Religiosity and Deviance: An Examination of the Moral Community and Antiasceticism Hypotheses among U.S. Adults. Journal for the Scientific Study of Religion 51: 809-20. [CrossRef]

Sun, Anna. 2013. Confucianism as a World Religion: Contested Histories and Contemporary Realities. Princeton: Princeton University Press.

Tamney, Joseph. 1998. Asian Popular Religions. In Encyclopedia of Religion and Society. Edited by William H. Swatos. Lanham: Rowman Altamira.

Tittle, Charles R., and Michael R. Welch. 1983. Religiosity and Deviance: Toward a Contingency Theory of Constraining Effects. Social Forces 61: 653-82. [CrossRef]

Trawick, Michelle W., and Roy M. Howsen. 2006. Crime and Community Heterogeneity: Race, Ethnicity, and Religion. Applied Economics Letters 13: 341-45. [CrossRef]

Tsai, Lily L. 2007. Accountability without Democracy: Solidary Groups and Public Goods Provision in Rural China. Cambridge: Cambridge University Press.

Van Tubergen, Frank, Manfred te Grotenhuis, and Wout Ultee. 2005. Denomination, Religious Context, and Suicide: Neo-Durkheimian Multilevel Explanations Tested with Individual and Contextual Data. American Journal of Sociology 111: 797-823. [CrossRef]

Wallace, John M., Ryoko Yamaguchi, Jerald G. Bachman, Patrick M. O’Malley, John E. Schulenberg, and Lloyd D. Johnston. 2007. Religiosity and Adolescent Substance Use: The Role of Individual and Contextual Influences. Social Problems 54: 308-27. [CrossRef]

Wang, Xiuhua, and Sungjoon Jang. 2017. Relationships between Religion and Deviance in a Largely Irreligious Country: Findings from the 2010 China General Social Survey. Deviant Behavior 38: 1120-40. [CrossRef] 
Weber, Max, and Hans H. Gerth. 1953. The Religion of China, Confucianism and Taoism. Philosophy 28: 187-89.

Welch, Michael R., Charles R. Tittle, and Thomas Petee. 1991. Religion and Deviance among Adult Catholics: A Test of the 'Moral Communities' Hypothesis. Journal for the Scientific Study of Religion 30: 159-72. [CrossRef]

Wenger, Jacqueline E. 2004. Official vs. Underground Protestant Churches in China: Challenges for Reconciliation and Social Influence. Review of Religious Research 46: 169-82. [CrossRef]

Yang, Ching-kun. 1961. Religion in Chinese Society: A Study of Contemporary Social Functions of Religion and Some of Their Historical Factors. Berkeley: University of California Press.

Yang, Fenggang. 2004. Between Secularist Ideology and Desecularizing Reality: The Birth and Growth of Religious Research in Communist China. Sociology of Religion 65: 101-19. [CrossRef]

Yang, Fenggang. 2005. Lost in the Market, Saved at McDonald's: Conversion to Christianity in Urban China. Journal for the Scientific Study of Religion 44: 423-41. [CrossRef]

Yang, Fenggang. 2006. The Red, Black, and Gray Markets of Religion in China. Sociological Quarterly 47: 93-122. [CrossRef]

Yang, Fenggang. 2010. Religion in China under Communism: A Shortage Economy Explanation. Journal of Church and State 52: 3-33. [CrossRef]

Yang, Fenggang. 2011. Religion in China: Survival and Revival under Communist Rule. New York: Oxford University Press.

Yang, Fenggang, and Anning Hu. 2012. Mapping Chinese Folk Religion in Mainland China and Taiwan. Journal for the Scientific Study of Religion 51: 505-21. [CrossRef]

Ying, Fuk-tsang. 2009. The Regional Development of Protestant Christianity in China: 1918, 1949 and 2004. China Review 9: 63-97.

Yu, Jianrong. 2010. China Underground Church Survey. Available online: http://phtv.ifeng.com/program/ shnjd/detail_2010_07/16/1783447_1.shtml (accessed on 12 November 2017).

Zhang, Jie, and Shenghua Jin. 1996. Determinants of Suicide Ideation: A Comparison of Chinese and American College Students. Adolescence 31: 451-67. [PubMed]

Zhang, Jie, and Darwin L. Thomas. 1994. Modernization Theory Revisited: A Cross-Cultural Study of Adolescent Conformity to Significant Others in Mainland China, Taiwan, and the USA. Adolescence 29: 885-903. [PubMed]

Zhang, Jie, and Huilan Xu. 2007. The Effects of Religion, Superstition, and Perceived Gender Inequality on the Degree of Suicide Intent: A Study of Serious Attempters in China. OMEGA Journal of Death and Dying 55: 185-97. [CrossRef] [PubMed]

Zhao, Jiubo, Xueling Yang, Rong Xiao, Xiaoyuan Zhang, Diane Aguilera, and Jingbo Zhao. 2012. Belief System, Meaningfulness, and Psychopathology Associated with Suicidality among Chinese College Students: A Cross-Sectional Survey. BMC Public Health 12: 668. [CrossRef] [PubMed] 